\title{
環太平洋地域第四紀島弧玄武岩類の 主化学組成とテクトニクス
}

\author{
高 橋 正 樹* \\ Major Elemental Chemistry of Quaternary \\ Arc Basalts in the Cricum-Pacific \\ Region and its Tectonic Implications
}

Masaki TAKAHASHI

\section{I.はじめに}

“島弧”は, 中央海嶺で生産された海洋性りソ スフェアーが再び上部マントルーと還元されて行 くプレート消費境界である。すなわち，“島弧” の性格を規定している最大の要因は, 沈み込む海 洋性リソスフェアーの性質にあるといえよう。海 洋性リソスフェアーの性質は, その形成年代と深 い関係を持っている。中央海嶺において部分溶融 した上部マントルから生成された海洋性リソスフ エアーは, 移動するにつれて 固化・冷却し, 密 度を增して行くからである (e.g. YosHII et al. 1976)。年代の古い海洋性リンスフェアーは冷た くて重く，これに対して年代の若いものは暖かく て軽い。したがって, 前者が沈み込めば, 冷たい ために周辺のマントルと熱的に同化しにくくより 深部にまで到達し得ると同時に, 重いために大き な負の浮力が働いて沈み込みの速度が速くなり, さらに沈み込みの角度も急になる。これに対し て，後者が沈み込めば，熱的に同化されやすいた めに到達深度が浅くなり，しかも軽いために負の 浮力が減少して沈み込み速度がおそくなり, 沈 み込み角度も浅くなる (e.g. RUFF and KANAMORI 1980)。また, 海洋性プレート上には, 厚さ $30 \mathrm{~km}$ におよぶ厚い地款を有する非震性海嶺 や海台あるいは微少大陸などが多数分布している
が (NUR and BEN-ABRAHAM 1982), これ らは密度が小さく軽いために，その沈み込みは年 代の若いプレートのそれと類似の効果をもたらす であろう。ここでは，形成年代や非震性海嶺・海 台の存在に応じて様々な性質を示す沈み込み海洋 性プレートの側から“島弧”を眺め直してみた い。島弧では一般にマグマ活動がみられるが，冷 たくて重くなったリンスフェアーが沈み込んで行 く場所でどうして熱くて軽いマグマが上昇してく るかは，これまで大きな謎とされてきた。“島 弧”が沈み込みプレートの運動によってその性格 を決定されているとすれば，島弧マグマ活動の成 因は，上部マントル全体を包括するような大きな 系で考えて行く必要があるだろう。一方，上部マ ントルで生成され得ることがほぼ確実なマグマは 玄武岩質のものである。したがって，上部マント ルの情報を最も良く伝達してくれるのは玄武岩質 マグマであるといえよう。以下では，島弧玄武岩 の主化学組成（特にアルカリ量）に着目し，沈み 込タプレートと島弧マグマ活動との関連につい て，環太平洋地域を例として検討してみたい。

II. 低アルカリ・ソレアイトと沈み込み プレート

日本列島は，ジュラ紀〜白亜紀の古い形成年代 を示す太平洋プレートの沈み込む東日本弧と, 古

* 茨城大学理学部地球科学教室 Department of Earth Sciences, Ibaraki University 
第三紀〜新第三紀の若い年代を有する フィリピン海プレートの沈み込む西日 本弧とからなっている。島弧立武岩は アルカリ量の低いものから順に，低ア リカリ・ソレアイト (LTH), 高アル ミナ玄武岩 $(\mathrm{HAB})$ ，アルカリ玄武岩 (AOB) の三つに区分されるが(KUNO 1960)，東日本弧火山フロント沿いに 噴出する玄武岩は，島弧会合部（中部 日本，北海道中央部）を除いて 全て LTH であり, 島弧会合部にのみ HAB が出現する (Fig. 1)。LTH の出現 と深発地震面の 到達深度 (e.g. 吉井 1979）との間には良い相関性があり, LTH は深発地震面が深さ $400 \mathrm{~km}$ 以 上にまで到達している場所にのみ出現 している。島弧会合部では深発地震面 の到達深度は $400 \mathrm{~km}$ 以下になり, LTH は噴出しなくなる。深発地震面がプレ 一トそのものを代表しているとすれ ば，LTH は沈み込みプレートが 400 $\mathrm{km}$ 以上の深部にまで到達している場 所にのみ出現していることになる。西 日本弧では，前期中新世の年代を示す 四国海盈の沈み込む中国地方〜九州中 部にかけては, AOB ないしはアルカリに富む $\mathrm{HAB}$ が噴出するが (Fig. 1)，これらの地域では 深発地震面の 到達深度は $200 \mathrm{~km}$ 以下である。一 方，古第三紀の年代を有するフィリピン海盈の沈 み込む南九州〜琉球列島にかけては，火山フロン トに HAB が出現し (Fig. 1)，深発地震面の到 達深度は $200 \mathrm{~km}$ を越えるが， $400 \mathrm{~km}$ には達し ていない。環太平洋地域で LTH の噴出する島弧 は, カムチャツカの一部, 千島列島, 東北日本, 伊豆・小笠原，マリアナ，サンギへおよびスン ダ・バンダ孤の一部，ニューブリテン，バヌアッ の一部，トンガ・ケルマディックなどであるが, いずれも深発地震面の到達深度は $400 \mathrm{~km}$ 以上 (600 700km) に達しており，多くの場合は沈み 込み速度も速く（7〜9 cm/年）また沈み込みの傾 斜角も急である。このうち海洋性プレートの沈み 込み速度と LTH の出現との関係については,す

Low alkali tholeiite High alumina basalt (1) Alkali basalt

- high alkali High alumina basalt

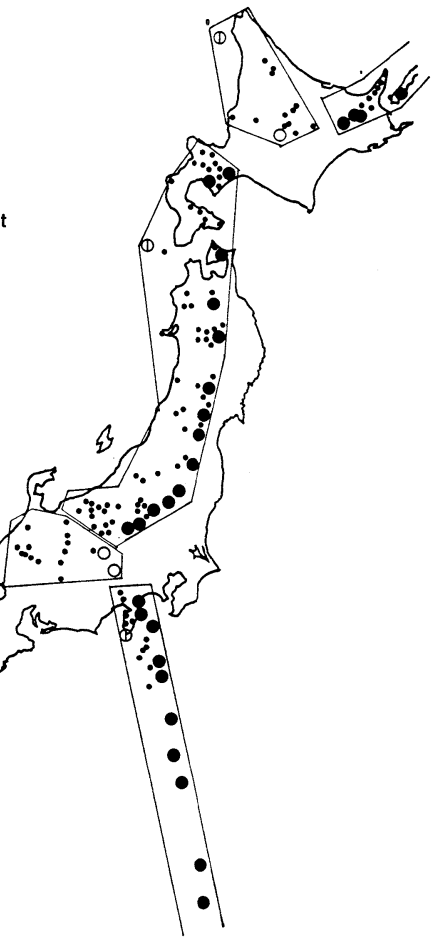

Fig. 1 Type of Quaternary arc basalts erupted in the volcanic front of Japanese islands. The volcanic belts of Japan are divided into seven segments based on types of frontal are basalts.

でに SUGIMURA and UYEDA (1973) や MIYASHIRO (1974) によっても指摘されている。LTH は，一部の例外を除いて，一般に形成年代が古く 冷たくて重い海洋性プレートの沈み込む島弧に特 徴的な玄武岩であるといえよう。

\section{III. 高アルミナ玄武岩中の $\mathrm{Na}_{2} \mathrm{O}$ 量と沈} み込みのプレートの年代

LTH の出現が限られているのに対して, $\mathrm{HAB}$ はほとんど全ての島弧に出現する。したが って, 沈み达みプレートの性質の違いが HAB の 主化学組成に反映されている可能性は大きいとい える。事実, $\mathrm{HAB}$ の $\mathrm{Na}_{2} \mathrm{O}$ 量に着目すると, 沈 み込みプレートの年代との間に良好な負の相関性 が認められる (Fig. 2)。年代の古い海洋性リソス フェアーの沈み込んでいる島弧では $\mathrm{Na}_{2} \mathrm{O}$ 量の 少ない $\mathrm{HAB}$ が，若い場合には $\mathrm{Na}_{2} \mathrm{O}$ 量の多い 


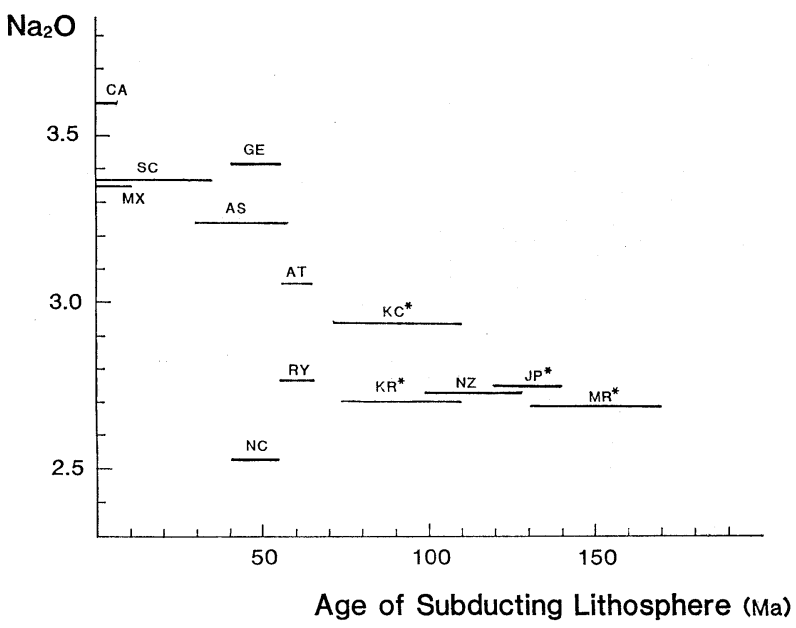

Fig. 2 Relationship between the average $\mathrm{Na}_{2} \mathrm{O}$ content (wt \%) of the circum-Pacific subduction zone highalumina basalts and the age (Ma) of subducting oceanic lithospheres (TAKAHASHI 1988). CA : Cascade; GE: Guatemala-eastern El Sarvador; SC: Southern Chile; MX: Mexico; AS : Alaska; AT: Aleutians; KC: Kamchatka ; KR : Kuriles; JP : Northeast Japan; MR : Marianas; NZ : New Zealand; RY : Ryukyus; NC : western E1 Sarvador-Nicaragua-eastern Costa Rica.

$\mathrm{HAB}$ が出現する。両者の間には $\mathrm{K}_{2} \mathrm{O}$ 量に関し ては顕著な違いは見出せない(Fig. 3)。例外は琉 球弧や中央アメリカのニカラグアのような, 活動 的な縁海を伴ったり引張テクトニクス場におかれ ている島弧である。 $\mathrm{HAB} の ~ \mathrm{Na}_{2} \mathrm{O}$ 量を支配する 要因としては, 先ず沈み达みプレートからマント ル・ウエッジへの海水の供給が考えられる。海水 中には $\mathrm{NaCl}$ が多量に含まれているので, その 量が増えればマントル中の $\mathrm{Na}_{2} \mathrm{O}$ 量も増大する だろう。海水中の ${ }^{87} \mathrm{Sr} / 86 \mathrm{Sr}$ 比は高いので，もし 大量の海水が供給されれば，マントル中の ${ }^{87} \mathrm{Sr} /$ ${ }^{86} \mathrm{Sr}$ 比も増大するので，それは $\mathrm{HAB} の{ }^{87 \mathrm{Sr}} /{ }^{86} \mathrm{Sr}$ 同位体比初生值にも反映されるはずである。しか し, $\mathrm{Na}{ }_{2} \mathrm{O}$ 量の違いに対応した $\mathrm{Sr}$ 同位体比の 違いはほとんど認められないので（e.g. NoTSU 1983 ; LOPEZ-ESCOBAR 1984), その可能性は は小さいといえる。次に考えられるのは，マグマ 成分のマントル・ウェッジからの除去の程度の違
いである。 $\mathrm{Na}_{2} \mathrm{O}$ はマグマの方に分配 されやすいので，その除去の程度が大 きければ, マントル中の $\mathrm{Na}_{2} \mathrm{O}$ 量は 減少するだろう。一方，マントルから のマグマ成分の除去の程度は $\mathrm{La} / \mathrm{Yb}$ 比にも反映される。もし部分溶融の程 度がほぼ同一ならぼ，除去の程度の高 いマントルから生成された HAB の $\mathrm{La} / \mathrm{Yb}$ 比は，低いものから導かれた ものよりも低くなるはずである。しか し, $\mathrm{HAB}$ 中の $\mathrm{La} / \mathrm{Yb}$ 比には $\mathrm{Na}_{2} \mathrm{O}$ 量の違いに対応した系統的差異は認 められないので (e.g. FUJIMAKI and KURASAWA 1980 ; LopeZ-EscoBAR 1984), この可能性も低いかもし れない。斜長石一カンラン石一透輝石 一（シリカ十カリ長石）系の斜長石一 透輝石共融線, カンラン石一透輝石共 融線は, 高圧になると斜長石側, カン ラン石側にそれぞれ移動する (BAKER and EGGLER 1983)。HAB 中の $\mathrm{Na}_{2} \mathrm{O}$ 量が高くなると $\mathrm{CaO}$ 量が低く なるので透輝石成分が減少し，結果と して高 $\mathrm{Na}_{2} \mathrm{O} \mathrm{HAB}$ 組成は高圧側の 共融線に沿ってプロットされる（CARR 1984）。 この事実は, 高 $\mathrm{Na}_{2} \mathrm{O} \mathrm{HAB}$ がより高圧下で結 晶分化した産物であることを示唆している。地喨 の下底部に玄武岩質マグマが停滞し，そこで結晶 分化作用を行なうことはありそうなことである。 したがって，地殼の厚さが異なれば，分化が生ず る圧力も異なるかもしれない（CARR 1984）。し かし，例えば高 $\mathrm{Na}_{2} \mathrm{O} \mathrm{HAB}$ の出現する南部チリ 一と低 $\mathrm{Na}_{2} \mathrm{O} \mathrm{HAB}$ が噴出する東北日本とでは 地殼の厚さ（約 $30 \sim 40 \mathrm{~km}$ ） に著しい違いは存在 しないので, 分化時の圧力の違いによって $\mathrm{Na} 2 \mathrm{O}$ 量の差を説明するのは困難のように思える。カン ラン岩から生成される玄武岩質マグマ中の $\mathrm{Na}_{2} \mathrm{O}$ 量が圧力に依存する事実は KUSHIRO（1968）に よってフォルステライトーシリカーネフェリン系 において初めて示された。また, TAKAHASHI and KUSHIRO (1983) のカンラン岩に関する溶融 実験結果においても, 圧力 $20 \mathrm{~kb}>$ では, 部分溶融 
の程度がほぼ同じならぼ，マグマ中の $\mathrm{Na}_{2} \mathrm{O}$ 量 は圧力に依存するようにみえる。したがって，マ ントル・ウェッジ内において，より高圧下では高 $\mathrm{Na}_{2} \mathrm{O} \mathrm{HAB}$ が，より低圧下では低 $\mathrm{Na}_{2} \mathrm{O} \mathrm{HAB}$ が，それぞれカンラン岩から直接形成される可能 性がある。今のところ, $\mathrm{HAB}$ の $\mathrm{Na}_{2} \mathrm{O}$ 量の差 は生成時の圧力の違いを反映していると考えるの が最も妥当性があるように思える。もしこれが事 実であるとすると，年代が古くて泠たく重い海 洋性プレートの沈み込む島弧ではより低圧下で $\mathrm{HAB}$ が生成し, 逆に年代が若くて暖かく軽い海 洋性リソスフェアーが沈み込む島弧ではより高圧 下で HAB が生成することになる。

\section{IV. 熱い海洋性リソスフェアー（中央} 海嶺）の沈み込み

現在, 環太平洋地域で中央海嶺（プレート生産 境界）が沈み込んでいる場所としては三ケ所が認 められている。東太平洋海嶺が 沈み込むメキシ コ, チリー海嶺の沈み込む南部チリー, そして拡 大中の縁海 (ウッドラーク海盈) の拡大軸が沈み 込むソロモン群島である。これらの地域では，い ずれも深発地震面の到達深度が $80 \mathrm{~km}>$ と浅く, 沈み込み角度も緩く, しかも地震の発生頻度も小 さい。メキシコやソロモン群島においては，火山 フロントが，拡大軸の沈み込む場所で大きく海溝 よりに前進しており，そこでは $\mathrm{K}_{2} \mathrm{O}$ に富み， $\mathrm{TiO}_{2}$ に乏しく $\left(\mathrm{K}_{2} \mathrm{O} / \mathrm{TiO}_{2}>2.0\right)$, しかも $\mathrm{MgO}$ に富んだ $\mathrm{AOB}$ が, $\mathrm{HAB}$ や高マグネシウム安 山岩を伴って賁出している (HASENAKA and CARMICHAEL 1987 ; RAMSAY et al. 1984)。 一方, 南部チリーでは, 中央海嶺が沈み込む場所 としては唯一 $\mathrm{TiO}_{2}$ に富む $\mathrm{AOB}$ が出現する。 以上のように, 熱くて軽い中央海嶺の沈み込みを 特徴づける島弧玄武岩は $\mathrm{AOB}$ であるといえる。 また, 拨大直後の熱いプレートの沈み込んでいる “島弧”としては，高 $\mathrm{Na}_{2} \mathrm{O} \mathrm{HAB}$ が噴出して いる北アメリカ西部のカスケード地域がある。そ こでは上部マントル中に非震性沈み込みスラブが 見出されており，それは約 $250 \mathrm{~km}$ の深度にまで 到達しているのが確涩されている(MICHAELSON and WEAVER 1986)。

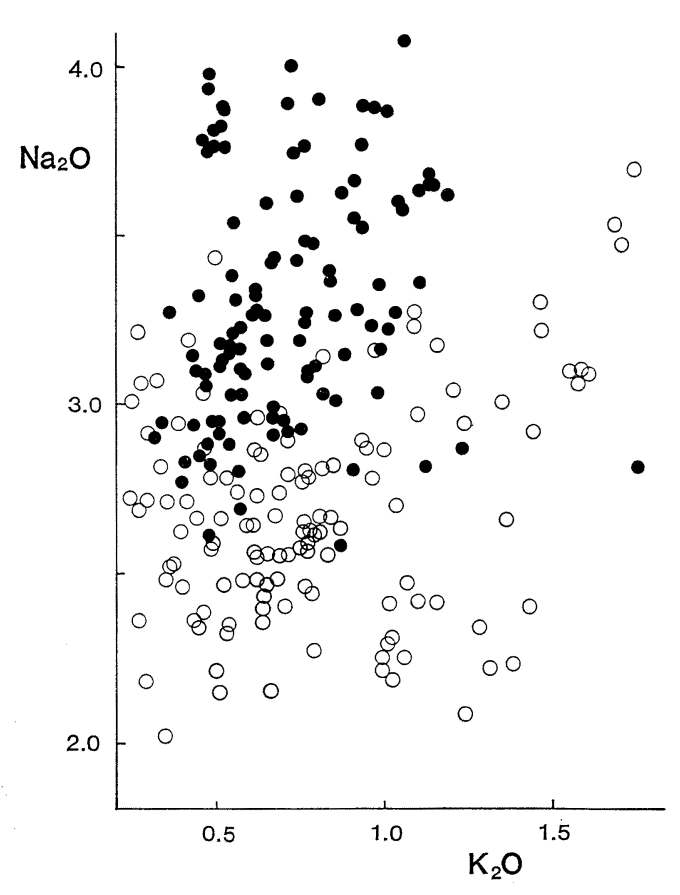

Fig. $3 \mathrm{Na}_{2} \mathrm{O}$ vs. $\mathrm{K}_{2} \mathrm{O}$ (wt\%) diagram for the high-alumina basalts of Northeast Japan (open circle) and Southern Chile(closed circle) (TAKahashi 1988).

\section{V. 非震性海嶺・海台・微少大陸の沈み込み}

密度の小さな非震性海嶺・海台・微少大陸が浮 揚性の沈み込みを行なうことによって，噴出する 島弧玄武岩の組成に変化が生じている場所として は, マーカス・ネッカー海嶺の沈夕込む伊豆・小 笠原弧硫黄島周辺, ダントルカトー海額の沈み込 むバヌアツ弧のエスピリッ・サント島付近, およ び微少大陸であるスンバ島の沈み込むスンダ弧の 一部などがある。これらの地域ではいずれも， $\mathrm{TiO}_{2}$ にそしく $(1.5 \%>)$ 比較的 $\mathrm{K}_{2} \mathrm{O}$ に富ん だ $\mathrm{AOB}$ が火山フロントに出現しており（福 山 1983 ; GORTON 1977; WHELLER et al. 1987)，周辺地域とは際だった対照をみせている。 こうした島弧では, 深発地震面が途中から海溝に 近づく方向に逆に屈曲していたり（硫黄島周辺； ISACKS and BARAZANGI 1977), 深発地震面 の到達深度が浅くなっていたり（バヌアッ；HA- 
NUŠ and VANEK 1983) しており, 海洋性プ レートの正常な沈み込みが擾乱されているのがわ かる。非震性海嶺・海台・微少大陸が沈み込む島 弧も, マグマ活動がみられる場合には，それは AOB で特徴づけられるといえよう。

\section{VI. 引張テクトニクス場にある島弧}

これまで，沈み込む海洋性リソスフェアーの性 質と沈み込み境界に噴出する島弧立武岩の種類と の関係について検討してきた。島弧玄武岩の種類 と沈み込みプレートの性質との間にはかなり良好 な相関性がみられるが，例外的な場所もいくつか 存在する。そうした例外的な島弧は，一般に明瞭 な引張テクトニクス場ないしはそれに近い状態に おかれている場合が多い。島弧が引張テクトニク 又場におかれるためには, 沈み込まれる側が後退 するか, あるいは沈み込む側が後退するかして， そこに引張応力が㗢く必要がある (e.g. UYEDA 1986)。沈み込む側が後退するか否かは沈み込み プレートの性質にも依存するが，沈み込まれる側 が後退する場合には, 沈み込みプレートとは直接 の関係はない。火山フロントが明瞭な引張テクト ニクス場におかれている島弧としては，中央アメ リカのニカラグア周辺やニュージーランド北島が ある。また，火山フロントのすぐ背弧側に拡大中 の緑海のような顕著な引張テクトニクス場を伴う 島弧として, 伊豆・小笠原弧, マリアナ弧, トン ガ・ケルマディック弧, バヌアツ弧, 南九州・琉 球弧などがある。これらの地域では, 低 $\mathrm{Na}_{2} \mathrm{O}$ $\mathrm{HAB}$ が出現するか，㐫るいはこれに加えて LTH が噴出している。上記のうちニカラグアと 南九州・琉球弧を除いた各島弧では, 年代が古く 冷たくて重い海洋性リソスフェアーが沈み込んで いる。ニカラグアはこれらの中で最も若い年代の リソスフェアーが沈み込んでいる “島弧”である が，そこでは沈み込まれる側のカリブ・プレート が海溝から遠ざかる方向に移動しており，このた めに火山フロント付近は明瞭な引張応力下にあ り, 海溝と平行な顕著なグラーベンが発達してい る。

\section{VII. 島弧玄武岩マグマの成因とテクトニクス}

島弧玄武岩質マグマのアルカリ量を規定してい る要因は, その生成深度 (圧力) と部分溶融度で ある (TAKAHASHI and KUSHIRO 1983; TATSUMI et al. 1983)。すなわち LTH, HAB, $\mathrm{AOB}$ の順に, その生成深度が増大し部分溶融度 は減少する。一方, 沈み込み海洋性リソスフェア 一の物理的性質と，そこ噴出する島弧玄武岩の 種類との間の良い相関性は, 沈み込みプレートの 物理的性質こそが，島弧マグマの生成を支配して いる最大の要因であることを示唆している。年代 が古く冷たくて重いリソスフェアーが沈み込んだ 場合に，かえって部分溶融度が高く，生成深度 も浅い LTH や, 生成深度の浅い可能性の高い低 $\mathrm{Na}_{2} \mathrm{O} \mathrm{HAB}$ が出現し, 逆に年代の若い熱くて軽 いプレートが沈み込んだり, 密度の小さな非震性 海嶺や海台, 微少大陸などが沈み込んだ場合に, むしろ部分溶融度が低く, 生成深度の深い $\mathrm{AOB}$ や, 生成深度の上り深い可能性の高い高 $\mathrm{Na}_{2} \mathrm{O}$ HAB が噴出している事実は, 例えば ToKsöZ and BIRD (1977), UYEDA (1986), 木下・伊 藤（1986）らの二次反転流モデルによって最も良 く説明できるように思える。プレートが沈み込む と, その直上の上部マントル物質は沈み込みの運 動に引きずられて深部へと移動して行く。する と，これを補償するように，傾斜した沈み込みス ラブと平行な反転上昇流がマントル・ウェッジ内 に生ずる。プレートの沈み込み速度が速い程, こ の反転流の速度も速くなるし, 到達深度が深くな る程, 逆により深部の高温物質が，友転流によっ てより浅所へと運ばれるであろう。より高温の物 質が断熱的に上昇すればやがてソリダスを越え部 分溶融が始まる。そして,より浅所へと上昇する 程, 部分溶融の度合は増大寸ることになる。一 方，こうした上昇流が引きずりによる下降流に転 ずる場所では, 前断応力が集中するためにメルト が濃集し，マントル・ウエッジ内に傾斜したメル 卜濃集層が形成される可能性が大きい（木下・伊 藤 1986)。傾斜したメルト濃集層内では, 液相 はより圧力の低い先端部へと濃集し，そこから分 離したマントル・ダイアピルはさらに上昇し, 最 
終的にマグマを地表へ供給して火山フロントを形 成する（MARSH 1979）。年代が古く冷たくて重 いプレートは, より速い速度でより媣部へと沈み 込む。したがって，それによって形成された二次 反転流は, 年代が若く暖かくて軽いプレートの沈 み込みによって生じたものよりも, より速くより 浅所へともたらされるだろう。その結果, 部分溶 融度が大きく低圧下で生じた LTH や上り低圧 下で生成された可能性の高い低 $\mathrm{Na}_{2} \mathrm{O} \mathrm{HAB}$ が 噴出する。これとは逆に, 年代の若いプレートが 沈み込んだ場合には, 二次的反転流は相対的に浅 所にしか到達できず, 部分溶融度が小さく高圧下 で形成された $\mathrm{AOB}$ や，より高圧下で生じた可 能性の大きい高 $\mathrm{Na}_{2} \mathrm{O} \mathrm{HAB}$ が, 火山フロントに 出現することになる。HORIE et al. (1984) は, 東北地方下のマントル・ウェッジ内に, 火山フロ ント直下へと連続して行く高温低速度層を見出し て抢り，また TATSUMI et al. (1983) の実験 結果は, 東北地方下のマントル・ウェッジ内に $1400^{\circ} \mathrm{C}$ 以上の高温部の存在を要請している。こ れらは，マントル・ウェッジ内を上昇する高温の 二次反転流の実在を支持しているようにみえる。 一方, 引張テクトニクス場は, 中央海嶺に抢いて 典型的にみられるように，マントル物質がより浅
所一と上昇しやすい環境を提供する。このため に，引張テクトニクス場におかれている島弧で は, リソスフェアーの沈み込みによる二次反転流 がより浅所へ々上昇する可能性が増大寸るのでは ないだろうか。島弧マグマ活動の成因に関する以 上のような考え方は，小林 (1987) によっても別 の観点から提示されている。島弧は冷却し重くな った物質が沈み込んで行く場所なので，本来は高 温物質の上昇流は生じないはずであるが，沈み込 み運動によって力学的に生じた二次的反転流が小 規模な高温物質の上昇流を形づくり，その断熱的 上昇と低圧下での部分溶融がマグマ生成の原因と なっていると考えるのが，島弧玄武岩の種類と沈 み込みリソスフェアーの物理的性質との閒の良好 な相関性についての最も自然な説明であるように 思われる。

\section{謝 辞}

本論の一部もしくは全部につき, 貴重なコメン トあるいは御討論をいただいた以下の方々に感謝 致します。 久城育夫教授 (東京大・理学部), 荒 牧重雄教授 (東京大学・地震研), 池田幸雄教授 (茨城大・理学部), 故中村一明教授 (東京大・地 霞研), 故小沼直樹教授 (茨城大・理学部).

\section{文献}

BAKER, D. H. and EGGLER, D. H. (1983) : Fractionation paths of Atka (Aleutians) high-alumina basalts: Constraints from phase relations. J. Volcanol. Geotherm. Res., 18, 387-404.

CARR, M. J. (1984) : Symmetrical and segmented variation of physical and geochemical characteristics of the Central America volcanic front. J. Volcanol. Geotherm. Res., 20, 231-252.

FuJIMAKI, H. and Kurasawa, H. (1980) : Lateral variation of REE pattern of basaltic magma across the Japan Arc. J. Jpn. Assoc. Mineral. Petrol. Econ. Geol., 75, 313-322.

福山博之 (1983)：火山列島, 南硫黄火山の地質. 地学雑誌, 92, 55-67.

GORTON, M. P. (1977) : The geochemistry and origin of Quternary volcanism in the New Hebrides. Geochim, Cosmochim Acta, 41, 1257-1270.

HANUš, V. and VANĚK, J. (1983) : Deep structure of the Vanuatu (New Hebrides) islandarc: intermediate depth collision of subducted lithospheric plates. N. Z. J. Geol. Geohys., 26, 133-154.

Hasenaka, T. and CARmichael, I. S. E. (1987): The cinder cones of MichoachanGuanajuato, Central Mexico: Petrology and Chemistry. J. Petrol., 28, 241-269.

HoRIE, H. K., IshII, H. and TAKAGI, A. (1984): Fine structure beneath the Tohoku district, Northeastern Japan arc, as derived by an inversion of $\mathrm{P}$-wave arrival times from local earthquakes. Tectonophysics, 101, 245-265.

ISACKS, B. L. and BARAZANGI, M. (1977) : Geometry of Benioff zones: Lateral segmenta- 
tion and downwards bending of the subducted lithoshere. in TALWANI, M. and PITMAN, W. C. (eds.), Island arcs, deep sea trenches and back-arc basins. A. G. U., 99-114.

木下 修・伊藤 英文 (1986) : マントル・ウェッジ部の誘起渦とマグマの発生. 火山第 2 集，31, 29-38.

小林洋二 (1987) : テクトニクスから見た島弧の第四紀火山活動. 火山第 2 集 第30巻特別号, S137S152.

Kuno, H. (1960) : High-alumina basalt. J. Petrol., 1, 121-145.

Kushiro, I. (1968) : Composition of magmas formed by partial zone melting in the earth's upper mantle. J. Geophys, Res., 73, 619-634.

LOPEZ-EsCOBAR, L. (1984) : Petrology and chemistry of volcanic rocks of the Southern Andes. in HARmon, R. S. and BARreiro, B. A. (eds), Andean magmatism: Chemical and isotopic constraints, Shiva, U. K., 47-71.

MARSH, B. D. (1979): Island arc development: some observations, experiments, and speculations. J. Geol, 87, 687-713.

Michaelsen, C. A. and Weaver, C. S. (1986): Upper mantle structure from teleseismic $\mathrm{P}$ wave arrivals in Washington and northern Orgen. J. Geophys. Res., 91, 2077-2094.

Miyashiro, A. (1974): Volcanic rock series in island arcs and active continental margin. Am. J. Sci., 274, 321-335.

Notsu, K. (1983) : Strontium isotope composition in volcanic rocks from the northeast Japan arc. J. Volcanol. Geotherm. Res., 18, 531-548.

Nur, A. and Ben-AvrahAm, Z. (1982): Oceanic plateaus, the fragmentation of continents, and mountain building. J. Geophys. Res., 87, 3644-3661.

RAmsay, W. R. H., Crawford, A. J., and Foden, J. D. (1984) : Field setting, mineralogy, chemistry, and genesis of arc picrites, New Georgia, Solomon Islands. Contrib. Min. Petrol., 88, 386-402.

RufF, L. and KAnAmori, H. (1980): Seismicity and the subduction process. Phys. Earth Planet. Inter., 23, 240-252.

Sugimura, A. and UyedA, S. (1973) : Island arcs-Japan and its environs. Elsevier, 247P.

TAKAHASHI, E. and KUSHIRo, I. (1983) : Melting of a dry peridotite at high pressures and basalt magma genesis, Am. Mineral., 68, 859-879.

TAKAHASHI, M. (1988) : On the $\mathrm{Na}_{2} \mathrm{O}$ content of convergent zone high-alumina basalts. Chem, Geol., 68, 17-29.

Tatsumi, Y., SAkuyama, M., Fukuyama, H. and Kushiro, I. (1983) : Generation of arc basalt magmas and thermal structure of the mantle wedge in the subduction zones. $J$. Geophys. Res., 88, 5815-5825.

Toksöz, M. N. and BIRD, P. (1977) : Formation and evolution of marginal basins and continental plateaus. in TALWANI, M. and PITMAN, W. C., Island arcs, deep sea trenches and back-arc basins. A. G. U., 379-394.

UYEDA, S. (1986) : Facts, ideas and open problems on trench-arc-back arc systems. in WEZEL, F. C. (ed.), The origin of arcs. Elsevier, 435-460.

Wheller, G. E., VArne, R., Foden, J. D. and AbbotT, M. J. (1987) : Geochemistry of Quaternary volcanism in the Sunda-Banda arc, Indonesia, and three-component genesis of island-arc basaltic magmas.

吉井敏越 (1979)：日本列島付近の地球物理データのコンパイル（I）. 地震研彙報, 54, 75-117.

Yoshir, T., Kono, Y. and ITO, K. (1976) : Thickening of the oceanic lithosphere, Geophys, Monogr. (A. G. U.)., 19, 423-430.

(昭和63年 2 月 2 日受理) 